Drug Alcohol Depend. 2014 November 1; 144: 265-269. doi:10.1016/j.drugalcdep.2014.08.007.

\title{
Attitudes of North Carolina law enforcement officers toward syringe decriminalization
}

\author{
Corey S. Davis ${ }^{a,{ }^{*}}$, Jill Johnston ${ }^{b}$, Lisa de Saxe Zerden ${ }^{c}$, Katie Clark ${ }^{d}$, Tessie Castillod, and \\ Robert Childs ${ }^{d}$ \\ a Network for Public Health Law - Southeastern Region, 101 E. Weaver St. \#G-7, Carrboro, NC \\ 27510, United States \\ b UNC Chapel Hill School of Public Health, Department of Epidemiology, 135 Dauer Dr, Chapel \\ Hill, NC 27599, United States \\ c UNC Chapel Hill School of Social Work, 325 Pittsboro St. CB\#3550, Chapel Hill, NC \\ 27599-3550, United States \\ d North Carolina Harm Reduction Coalition, 1005 Slater Road Suite 330, Durham, NC 27703, \\ United States
}

\section{Abstract}

Background-North Carolina, like much of the U.S. South, is disproportionately affected by HIV and hepatitis. This persistently high disease burden may be driven in part by laws that criminalize the possession and distribution of syringes for illicit drug use. Legal change to decriminalize syringes may reduce infection rates in the state, but is unlikely absent support from law enforcement actors.

Methods-We analyzed the responses of 350 North Carolina law enforcement officers to a confidential, anonymous survey. The survey instrument collected data regarding self-reported needle-stick injury (NSI), blood borne disease risk perception and attitudes toward syringe decriminalization.

Results- $82 \%$ of respondents reported that contracting HIV was a "big concern" for them. 3.8\% of respondents reported ever receiving a job-related NSI, a rate of 36 NSI per 10,000 officer-years. Majorities of respondents reported positive views regarding syringe decriminalization, with approximately 63\% agreeing that it would be "good for the community" and 60\% agreeing that it would be "good for law enforcement." Black and female officers were significantly less likely to

\footnotetext{
(C) 2014 Elsevier Ireland Ltd. All rights reserved.

*Corresponding author. Tel.: +1 919968 6308x105; fax: +1 919968 8855. cdavis@ networkforphl.org (C.S. Davis). jillj@unc.edu (J. Johnston), Izerden@unc.edu (L. de Saxe Zerden), Katie.clark@yale.edu (K. Clark), Tessie@nchrc.net (T. Castillo), Robert@nchrc.net (R. Childs).

Contributors

C. Davis conceptualized and drafted the article. J. Johnston and K. Clark conducted data analysis. L. Zerden contributed to the research and writing. R. Childs and T. Castillo designed and conducted the training. All authors reviewed and approved the submitted manuscript.

Conflict of interest

No conflict declared.
} 
agree that on-the-job NSI was a "big concern" and significantly more likely to agree that it would be good for law enforcement.

Conclusions-These findings suggest that many North Carolina LEOs understand the public health benefits of syringe access programs and may be inclined to support syringe decriminalization legislation. Further research is indicated to determine the causes of observed differences in perceptions of bloodborne disease risk and attitudes toward syringe decriminalization by race and sex.

\section{Keywords}

Injection drug use; Law enforcement; HIV; Syringe; Policy

\section{Introduction}

The burden of bloodborne disease in the United States falls disproportionately on those living in the South (Lansky et al., 2010; Qian et al., 2006), which has higher HIV and hepatitis $\mathrm{C}(\mathrm{HCV})$ incidence rates and more people living with HIV than any other region (Centers for Disease Control and Prevention, 2013a,b,c,d; Zou et al., 2010). In 2011, North Carolina had the country's 8th highest HIV incidence rate, the 12th highest number of cumulative AIDS cases, and an HCV incidence rate 50\% greater than the national average (Centers for Disease Control and Prevention, 2013a,b,c,d; North Carolina Division of Public Health, 2013).

Nearly $23 \%$ of all AIDS cases in North Carolina are attributable to injection drug use (IDU) alone, with an additional $5.6 \%$ of cases among men who have sex with men (MSM) who also reported IDU (Centers for Disease Control and Prevention, 2012). Nationwide, IDU is the leading risk factor for HCV infection (Centers for Disease Control and Prevention, 2002, 2013a). While acute HCV infections among Blacks have fallen over the past decade (Centers for Disease Control and Prevention, 2013a,b,c,d), HIV continues to be disproportionately distributed by race: Blacks comprise only $22 \%$ of North Carolina's population but 67\% of AIDS cases (Centers for Disease Control and Prevention, 2012; United States Census Bureau, 2012).

Law and law enforcement practices that reduce access to new syringes and opportunities to safely dispose of used ones are a key factor in injection-related disease transmission and may contribute to racial disparities in HIV rates (Blankenship and Koester, 2002;

Bluthenthal et al., 1997; Burris et al., 2002, 2011; Burris and Koester, 2013; Davis et al., 2005). Increased access to sterile syringes has been associated with a number of positive changes in health behavior and disease risk among people who inject drugs (PWID), including reductions in HIV and HCV infections, risky injecting behavior and improperly discarded syringes (Des Jarlais et al., 2005; Gibson et al., 2001; Hurley et al., 1997; Strathdee et al., 2006; Wodak and Cooney, 2006). Legal change to increase access to syringes has also been associated with reduced needlestick injuries (NSI) among law enforcement officers (LEOs; Groseclose et al., 1995) and may reduce the risk of NSI-related infection. 
Modifying law to permit or require evidence-based public health strategies is a critical component in improving health outcomes (Hodge et al., 2013; Mello et al., 2013). Many states have responded to the large body of evidence that increased syringe access reduces infection risk without increasing drug use by modifying criminal law to permit the possession and distribution of syringes, a policy termed syringe decriminalization (Burris, 2014). Southern states have largely failed to make such amendments. As of 2014, only one Southern state (Louisiana) permitted the distribution of syringes intended to be used to inject illegal drugs, and none permitted the possession of syringes for that purpose (Burris, 2014). This failure may contribute to persistently high rates of HIV infection in North Carolina and throughout the South (Adimora et al., 2014; Human Rights Watch, 2010; Reif et al., 2012).

North Carolina has been a leader among Southern states in some areas related to syringe access. It is legal to purchase syringes in pharmacies without a prescription in the state, although sales are at the discretion of the pharmacist and research has demonstrated that Black PWID are far less likely than whites to report receiving syringes from a pharmacy (Costenbader et al., 2010). Additionally, a state law partially decriminalizing syringes was implemented in 2013. The law protects a person from charge or prosecution for paraphernalia possession if he or she is stopped by a law enforcement officer (LEO) and voluntarily reports the syringe or other sharp object to the LEO before a search is conducted (North Carolina General Assembly, 2013a,b). Possession or distribution of syringes for illegal drug use, however, remains illegal.

Law enforcement support is likely an important factor in both the passage and implementation of syringe access and syringe decriminalization laws (Beletsky et al., 2005b; Silverman et al., 2012). Several previous initiatives have bundled LEO occupational safety training with information regarding the legality and beneficial effects of such laws (Beletsky et al., 2011; Davis and Beletsky, 2009; Silverman et al., 2012), but little is known regarding LEO attitudes toward them. Research from several Northern states reported that LEOs were generally supportive of efforts to reduce risks associated with drug use (Banta-Green et al., 2013; Beletsky et al., 2005a; Green et al., 2013), but none asked about syringe decriminalization specifically. We present below the results of the first such survey conducted among LEOs in the Southern United States.

\section{Methods}

Data were collected via surveys designed and administered by a local non-profit organization that conducted trainings for officers training to join Crisis Intervention Teams (CITs). These teams are comprised of LEOs, often in conjunction with other professionals such as mental health workers, who utilize evidence-based approaches in interacting with people in acute mental health need (Watson and Fulambarker, 2012). The hour-long training, delivered at multiple sites throughout the state in 2012 and 2013, provided an overview of HIV and other bloodborne disease transmission and guidance on ways LEOs can reduce their risk of on-the-job disease transmission.

Staff members from the non-profit organization administered the voluntary, anonymous survey prior to the training session. The survey instrument collected demographic data and 
queried respondents regarding bloodborne disease risk perception, their NSI experience, and attitudes toward policies such as syringe decriminalization that might reduce NSI. This study was deemed exempt by the University of North Carolina IRB because it was limited to an analysis of already-existing data collected by the non-profit organization in the regular course of its training activities.

Likert scale responses - "strongly agree," "agree," "disagree," and "strongly disagree" were dichotomized into "agree" and "disagree" for the analysis. Descriptive statistics were compiled for each question and assessed by race (Black vs. non-Black) and gender (male vs. female). Differences in attitudes by race or gender were assessed using a multivariate logistic model with an a priori significance level of 0.05. Adjusted odds ratios (AOR) for race and gender, controlling for age (represented by a quadratic polynomial) were calculated. We further evaluated for any gender by race interactions. Respondents with missing data were excluded from the analysis.

\section{Results}

The convenience sample consisted of 350 officers from 20 law enforcement agencies throughout North Carolina. Approximately $80 \%$ of respondents were male and, on average, had worked in law enforcement for approximately 10 years. Approximately $25 \%$ reported their race as Black, and 65\% as white (Table 1). Eighty two percent of respondents reported that contracting HIV and $85 \%$ reported that contracting hepatitis was a "big concern" for them, far exceeding the percentage that reported ever receiving an NSI (3.8\%, a rate of 36 NSI per 10,000 officer-years). Most respondents reported favorable views of syringe decriminalization. Fifty seven percent did not believe that syringe decriminalization would promote drug use, and approximately $60 \%$ reported that their impression of it was generally positive, that it would reduce HIV, and that it would be "good for the community" and "good for law enforcement" (Table 2).

Responses to several questions varied by race and gender. Black officers were approximately 20 percentage points less likely than white officers to report concern for onthe-job NSI (Q2: AOR 0.38, $p=0.005)$, were approximately 15 percentage points more likely to believe syringe decriminalization would be good for the community (Q6: AOR $1.83, p<0.035$ ), and 20 percentage points more likely to believe that it would be good for law enforcement $(\mathrm{Q} 7$ : AOR 2.31, $p=0.004)$. Female officers were approximately 30 percentage points less likely than males to report that they feared contracting HIV (Q1: AOR $0.18, p<0.001$ ), ten percentage points more likely to believe that syringe decriminalization would be good for the community (Q6: AOR 1.42, $p=0.24$ ), and 20 percentage points more likely to believe that it would be good for law enforcement (Q7: AOR 1.34, $p=0.007$ ). There was no significant interaction between race and gender in the responses.

\section{Discussion}

Law enforcement support appears to have been an important factor in the passage of North Carolina's 2013 partial decriminalization law. Bills intended to increase access to sterile 
syringes were introduced in six of the nine legislative sessions between 1997 and 2013 (North Carolina General Assembly, 1997, 2001, 2005, 2007, 2011, 2013b). None garnered the public support of LEO organizations, and all died in committee. Conversely, the 2013 law, which was co-sponsored by a legislator who was a former LEO and was supported by the state Sheriffs' Association (Sisk, 2013), was approved by nearly unanimous votes in both houses and was quickly signed by the governor (North Carolina General Assembly, 2013a,b). This experience suggests that LEO support for a full decriminalization measure would likely be helpful, and might be necessary, for such a bill to become law.

LEO support is also an important component of successful syringe access law implementation. Research from both the U.S. and abroad finds that LEOs generally do not favor focusing policing activities on drug users (Beyer et al., 2002; Petrocelli et al., 2014), and recent evidence suggests that officers are generally supportive of public health efforts to reduce risks associated with illicit drug use (Banta-Green et al., 2013; Davis et al., 2014; Green et al., 2013). However, there are many documented instances of LEOs failing to properly implement laws improving access to sterile syringes, possibly because they do not support the laws or understand their public health underpinnings (Beletsky et al., 2013; Burris and Koester, 2013; Davis et al., 2005; Heller et al., 2009; Martinez et al., 2007).

The rate of NSI in this cohort was somewhat higher than that reported elsewhere, but data on officer NSI risk is sparse, dated, and difficult to compare directly. A retrospective study of police officers in Amsterdam from 2000-2003 found NSI risk to be 6.7 per 10,000 officers per year (Sonder et al., 2005). A survey of 803 police officers in San Diego in 1996 reported that $46.2 \%$ of respondents reported ever having received a job-related NSI, but the response rate was below 50\%, and annual rates were not reported (Lorentz et al., 2000). An analysis of police and corrections officers reporting to emergency departments in Rhode Island between 1995 and 2001 found the average yearly incidence of percutaneous exposures to be 3.9 per 10,000 personnel (Merchant et al., 2008). Finally, a retrospective analysis of selfreported NSI among New York City Police Department officers revealed an exposure rate of 4.8 NSI per 10,000 officers in 1992 (Pagane et al., 1996). While these rates are generally lower than those reported among EMS responders (Leiss, 2010; Leiss et al., 2006), they present a non-negligible risk - a risk that would likely be lowered by the adoption of syringe decriminalization laws.

\subsection{Limitations}

This cohort, which was comprised of LEOs who had volunteered or been selected by their departments to join CITs, is not necessarily representative of all officers in the state. The questionnaire asked if respondents have ever received an NSI, but did not ask if they had received more than one, possibly leading to under-counting. Although multivariate models were utilized in this short communication, future analysis utilizing more sophisticated models would be useful in refining analyses.

\subsection{Conclusions}

Law enforcement agencies are increasingly adopting evidence-based strategies to reduce the negative effects of drug use (Banta-Green et al., 2013; Davis et al., 2014; Green et al., 
2013). A majority of the LEOs in this study reported positive views toward syringe decriminalization, suggesting that they may be inclined to support and properly implement syringe decriminalization legislation.

These findings also highlight several promising areas for further inquiry. Research is indicated to determine whether the variations in perception of NSI risk and attitudes toward syringe decriminalization by race and sex identified here are replicated in other cohorts both in North Carolina and nationwide, and to determine the possible causes of those differences. There is a pressing need for comprehensive, timely data regarding rates of officer NSI as well as the effects of legal changes intended to reduce that risk. Finally, further research is indicated to determine whether receiving information regarding the benefits of increased syringe access to LEO occupational risk modifies attitudes regarding syringe access laws, and whether a causal effect between LEO support for syringe access legislation and the passage of that legislation can be substantiated.

\section{Acknowledgement}

The authors thank Leo Beletsky for helpful comments on earlier versions of the manuscript.

Role of funding source

Nothing declared.

\section{References}

Adimora AA, Ramirez C, Schoenbach VJ, Cohen MS. Policies and politics that promote HIV infection in the Southern United States. AIDS. 2014; 28:1393-1397. [PubMed: 24556871]

Banta-Green CJ, Beletsky L, Schoeppe JA, Coffin PO, Kuszler PC. Police officers' and paramedics' experiences with overdose and their knowledge and opinions of Washington State's drug overdosenaloxone-Good Samaritan law. J. Urban Health. 2013; 90:1102-1111. [PubMed: 23900788]

Beletsky L, Agrawal A, Moreau B, Kumar P, Weiss-Laxer N, Heimer R. Police training to align law enforcement and HIV prevention: preliminary evidence from the field. Am. J. Public Health. 2011; 101:2012-2015. [PubMed: 21940924]

Beletsky L, Burris S, Macalino G. Attitudes of police officers towards syringe access, occupational needle-sticks, and drug use: a qualitative study of one city police department in the United States. Int. J. Drug Policy. 2005a; 16:7.

Beletsky L, Lozada R, Gaines T, Abramovitz D, Staines H, Vera A, Rangel G, Arredondo J, Strathdee SA. Syringe confiscation as an HIV risk factor: the public health implications of arbitrary policing in Tijuana and Ciudad Juarez, Mexico. J. Urban Health. 2013; 90:284-298. [PubMed: 22806453]

Beletsky L, Macalino GE, Burris S. Attitudes of police officers towards syringe access, occupational needle-sticks, and drug use: a qualitative study of one city police department in the United States. Int. J. Drug Policy. 2005b; 16:8.

Beyer L, Crofts N, Reid G. Drug offending and criminal justice responses: practitioners' perspectives. Int. J. Drug Policy. 2002; 13:9.

Blankenship KM, Koester S. Criminal law, policing policy, and HIV risk in female street sex workers and injection drug users. J. Law Med. Ethics. 2002; 30:548-559. [PubMed: 12561263]

Bluthenthal RN, Kral AH, Lorvick J, Watters JK. Impact of law enforcement on syringe exchange programs: a look at Oakland and San Francisco. Med. Anthropol. 1997; 18:61-83. [PubMed: 9458668]

Burris, S. LawAtlas: Syringe Possession Laws Map. 2014. http://lawatlas.org/query? dataset=paraphernalia-laws 
Burris S, Anderson E, Craigg A, Davis C, Case P. Racial disparities in injection-related HIV: a case study of toxic law. Temple Law Rev. 2011; 82:1263-1307.

Burris S, Koester S. Investigating the intersection of policing and public health. PLOS Med. 2013; 10:e1001571. [PubMed: 24339754]

Burris S, Welsh J, Ng M, Li M, Ditzler A. State syringe and drug possession laws potentially influencing safe syringe disposal by injection drug users. J. Am. Pharm. Assoc. 2002; 42:S94-S98.

Centers for Disease Control and Prevention. Viral Hepatitis And Injection Drug Users, Atlanta. 2002

Centers for Disease Control and Prevention. North Carolina - 2010 Profile, Atlanta. 2012

Centers for Disease Control and Prevention. Acute Hepatitis C Reports by Risk Behavior-United States, 2011, Atlanta. 2013a

Centers for Disease Control and Prevention. HIV Surveillance Report. Diagnoses of HIV Infection in the United States and Dependent Areas, 2011, Atlanta. 2013b; 23

Centers for Disease Control and Prevention. Incidence of Acute Hepatitis C by Race/EthnicityUnited States, 2000-2011, Atlanta. 2013c

Centers for Disease Control and Prevention. Reported Cases of Acute Hepatitis C by State-United States, 2007-2011, Atlanta. 2013d

Costenbader EC, Zule WA, Coomes CC. Racial differences in acquisition of syringes from pharmacies under conditions of legal but restricted sales. Int. J. Drug Policy. 2010; 21:425-428. [PubMed: 20097052]

Davis CS, Beletsky L. Bundling occupational safety with harm reduction information as a feasible method for improving police receptiveness to syringe access programs: evidence from three U.S. cities. Harm Reduct. J. 2009; 6:16. [PubMed: 19602236]

Davis CS, Burris S, Kraut-Becher J, Lynch KG, Metzger D. Effects of an intensive street-level police intervention on syringe exchange program use in Philadelphia, PA. Am. J. Public Health. 2005; 95:233-236. [PubMed: 15671455]

Davis CS, Ruiz S, Glynn P, Picariello G, Walley AY. Expanded access to naloxone among firefighters, police officers, and emergency medical technicians in Massachusetts. Am. J. Public Health. 2014; 104:e7-e9. [PubMed: 24922133]

Des Jarlais DC, Perlis T, Arasteh K, Torian LV, Beatrice S, Milliken J, Mildvan D, Yancovitz S, Friedman SR. HIV incidence among injection drug users in New York City, 1990 to 2002: use of serologic test algorithm to assess expansion of HIV prevention services. Am. J. Public Health. 2005; 95:1439-1444. [PubMed: 15985649]

Gibson DR, Flynn NM, Perales D. Effectiveness of syringe exchange programs in reducing HIV risk behavior and HIV seroconversion among injecting drug users. AIDS. 2001; 15:1329-1341. [PubMed: 11504954]

Green TC, Zaller N, Palacios WR, Bowman SE, Ray M, Heimer R, Case P. Law enforcement attitudes toward overdose prevention and response. Drug Alcohol Depend. 2013; 133:677-684. [PubMed: 24051061]

Groseclose SL, Weinstein B, Jones TS, Valleroy LA, Fehrs LJ, Kassler WJ. Impact of increased legal access to needles and syringes on practices of injecting-drug users and police officers Connecticut, 1992-1993. J. Acquir. Immune Defic. Syndr. Hum. Retrovirol. 1995; 10:82-89. [PubMed: 7648290]

Heller DI, Paone D, Siegler A, Karpati A. The syringe gap: an assessment of sterile syringe need and acquisition among syringe exchange program participants in New York city. Harm Reduct. J. 2009; 6:1. [PubMed: 19138414]

Hodge JG Jr. Barraza L, Bernstein J, Chu C, Collmer V, Davis C, Griest MM, Hammer MS, Krueger J, Lowrey KM, Orenstein DG. Major trends in public health law and practice: a network national report. J. Law Med. Ethics. 2013; 41:737-745. [PubMed: 24088165]

Human Rights Watch. Southern Exposure: Human Rights and HIV in the Southern United States, New York, NY. 2010:24.

Hurley SF, Jolley DJ, Kaldor JM. Effectiveness of needle-exchange programmes for prevention of HIV infection. Lancet. 1997; 349:1797-1800. [PubMed: 9269214]

Lansky A, Brooks JT, DiNenno E, Heffelfinger J, Hall HI, Mermin J. Epidemiology of HIV in the United States. J. AIDS. 2010; 2(Suppl. 55):S64-S68. 
Leiss JK. Management practices and risk of occupational blood exposure in U.S. paramedics: needlesticks. Am. J. Ind. Med. 2010; 53:866-874. [PubMed: 20698019]

Leiss JK, Ratcliffe JM, Lyden JT, Sousa S, Orelien JG, Boal WL, Jagger J. Blood exposure among paramedics: incidence rates from the national study to prevent blood exposure in paramedics. Ann. Epidemiol. 2006; 16:720-725. [PubMed: 16581265]

Lorentz J, Hill L, Samimi B. Occupational needlestick injuries in a metropolitan police force. Am. J. Prev. Med. 2000; 18:146-150. [PubMed: 10698245]

Martinez AN, Bluthenthal RN, Lorvick J, Anderson R, Flynn N, Kral AH. The impact of legalizing syringe exchange programs on arrests among injection drug users in California. J. Urban Health. 2007; 84:423-435. [PubMed: 17265133]

Mello MM, Wood J, Burris S, Wagenaar AC, Ibrahim JK, Swanson JW. Critical opportunities for public health law: a call for action. Am. J. Public Health. 2013; 103:1979-1988. [PubMed: 24028265]

Merchant RC, Nettleton JE, Mayer KH, Becker BM. HIV post-exposure prophylaxis among police and corrections officers. Occup. Med. 2008; 58:502-505.

North Carolina Division of Public Health. 2011 HIV/STD Surveillance Report, Raleigh, N.C. 2013

North Carolina General Assembly. Needle Exchange Pilot Program. 1997

North Carolina General Assembly. Clean Syringe - Safe Syringe Exchange Program. 2001

North Carolina General Assembly. Funds for Clean Syringe Program. 2005

North Carolina General Assembly. Funds for Needle Exchange Programs. 2007

North Carolina General Assembly. Reduce Needle Stick Injuries. 2011

North Carolina General Assembly. Possession of Needles/Tell Law Officer. 2013a

North Carolina General Assembly. Reduce Needle Stick Injuries. 2013b

Pagane J, Chanmugam A, Kirsch T, Kelen GD. New York city police officers incidence of transcutaneous exposures. Occup. Med. 1996; 46:285-288.

Petrocelli M, Oberweis T, Smith M, Petrocelli J. Assessing police attitudes toward drugs and drug enforcement. Am. J. Crim. Justice. 2014; 39:22-40.

Qian HZ, Taylor RD, Fawal HJ, Vermund SH. Increasing AIDS case reports in the South: U.S. trends from 1981-2004. AIDS Care. 2006; 18(Suppl. 1):S6-S9. [PubMed: 16938669]

Reif, S.; Whetten, K.; Wilson, E. HIV/AIDS Epidemic in the South Reaches Crisis Proportions in Last Decade. Duke Center for Health Policy and Inequalities Research; Durham: 2012.

Silverman B, Davis CS, Graff J, Bhatti U, Santos M, Beletsky L. Harmonizing disease prevention and police practice in the implementation of HIV prevention programs: up-stream strategies from Wilmington, Delaware. Harm Reduct. J. 2012; 9:17. [PubMed: 22591836]

Sisk, T. House passes syringe bill, Governor signs Good Samaritan into law. N. C. Health News; 2013.

Sonder GJ, Bovee LP, Coutinho RA, Baayen D, Spaargaren J, van den Hoek A. Occupational exposure to bloodborne viruses in the Amsterdam police force, 2000-2003. Am. J. Prev. Med. 2005; 28:169-174. [PubMed: 15710272]

Strathdee SA, Ricketts EP, Huettner S, Cornelius L, Bishai D, Havens JR, Beilenson P, Rapp C, Lloyd JJ, Latkin CA. Facilitating entry into drug treatment among injection drug users referred from a needle exchange program: results from a community-based behavioral intervention trial. Drug Alcohol Depend. 2006; 83:225-232. [PubMed: 16364566]

United States Census Bureau. State \& County QuickFacts: North Carolina. 2012

Watson AC, Fulambarker AJ. The crisis intervention team model of police response to mental health crises: a primer for mental health practitioners. Best Pract. Ment. Health. 2012; 8:71. [PubMed: 24039557]

Wodak A, Cooney A. Do needle syringe programs reduce HIV infection among injecting drug users: a comprehensive review of the international evidence. Subst. Use Misuse. 2006; 41:777-813. [PubMed: 16809167]

Zou S, Dorsey KA, Notari EP, Foster GA, Krysztof DE, Musavi F, Dodd RY, Stramer SL. Prevalence, incidence, and residual risk of human immunodeficiency virus and hepatitis $\mathrm{C}$ virus infections among United States blood donors since the introduction of nucleic acid testing. Transfusion (Paris). 2010; 50:1495-1504. 


\section{Table 1}

Demographics of respondents.

\begin{tabular}{ll}
\hline Characteristic & Number (\%) reporting \\
\hline Sex & \\
Male & $276(79.3 \%)$ \\
Female & $72(20.7 \%)$ \\
Race/ethnicity & \\
White & $227(65.0 \%)$ \\
Black & $89(25.5 \%)$ \\
Hispanic & $16(4.6 \%)$ \\
Other & $14(4.0 \%)$ \\
Asian & $3(0.9 \%)$ \\
Age & \\
$20-29$ & $91(26.4 \%)$ \\
$30-39$ & $111(32.2 \%)$ \\
$40-49$ & $108(31.3 \%)$ \\
$50-59$ & $31(9.0 \%)$ \\
$60-69$ & $4(1.2 \%)$ \\
Years in law enforcement & \\
$<5$ & $118(33.8 \%)$ \\
$5-10$ & $68(19.5 \%)$ \\
$11-15$ & $54(15.5 \%)$ \\
$16-20$ & $54(15.5 \%)$ \\
$21-25$ & $42(12.0 \%)$ \\
$25+$ & $13(1.4 \%)$ \\
Mean & 10.3 years \\
NSI risk & \\
Officers reporting NSI & $13(3.8 \%)$ \\
NSI rate & $36 / 10,000$ \\
\hline
\end{tabular}

NSI - needlestick injury. 
Table 2

Portion of respondents agreeing with statement, by race and gender.

\begin{tabular}{|c|c|c|c|c|c|c|c|}
\hline \multirow{2}{*}{$\begin{array}{l}\text { Proportion of } \\
\text { respondents } \\
\text { who agreed } \\
\text { with statement }\end{array}$} & \multirow[t]{2}{*}{ All } & \multicolumn{3}{|l|}{$\underline{\text { Race }}$} & \multicolumn{3}{|l|}{ Gender } \\
\hline & & $\begin{array}{l}\text { Non-Black } \\
(n=261)\end{array}$ & $\begin{array}{l}\text { Black }(\mathbf{n}= \\
\text { 89) }\end{array}$ & Adjusted odds ratio $^{a}$ & $\begin{array}{l}\text { Male }(n= \\
\text { 276) }\end{array}$ & $\begin{array}{l}\text { Female (n } \\
=72)\end{array}$ & Adjusted odds ratio $b$ \\
\hline $\begin{array}{l}\text { Q1. Getting HIV } \\
\text { from drug users } \\
\text { is a big concern } \\
\text { for me }\end{array}$ & $288(82.3 \%)$ & $227(87.0 \%)$ & $61(68.5 \%)$ & $\begin{array}{l}0.49 \\
p=0.027\end{array}$ & $244(88.4 \%)$ & $42(58.3 \%)$ & $\begin{array}{l}0.18 \\
p<0.001\end{array}$ \\
\hline $\begin{array}{l}\text { Q2. Getting } \\
\text { hepatitis from a } \\
\text { needle-stick } \\
\text { injury is a big } \\
\text { concern for me }\end{array}$ & $299(85.4 \%)$ & $235(90.0 \%)$ & $64(71.9 \%)$ & $\begin{array}{l}0.38 \\
p=0.005\end{array}$ & $247(89.5 \%)$ & $50(69.4 \%)$ & $\begin{array}{l}0.30 \\
p<0.001\end{array}$ \\
\hline $\begin{array}{l}\text { Q3. State wide } \\
\text { syringe } \\
\text { decriminalization } \\
\text { would promote } \\
\text { drug use }\end{array}$ & $151(43.1 \%)$ & $117(44.8 \%)$ & $34(38.2 \%)$ & $\begin{array}{l}0.80 \\
p=0.41\end{array}$ & $124(44.9 \%)$ & $26(36.1 \%)$ & $\begin{array}{l}0.72 \\
p=0.25\end{array}$ \\
\hline $\begin{array}{l}\text { Q4. My } \\
\text { impression of } \\
\text { syringe } \\
\text { decriminalization } \\
\text { is generally } \\
\text { positive }\end{array}$ & $214(61.1 \%)$ & $153(58.6 \%)$ & $61(68.5 \%)$ & $\begin{array}{l}1.38 \\
p=0.24\end{array}$ & $166(60.1 \%)$ & $47(65.3 \%)$ & $\begin{array}{l}1.16 \\
p=0.61\end{array}$ \\
\hline $\begin{array}{l}\text { Q5. Syringe } \\
\text { decriminalization } \\
\text { would help } \\
\text { reduce HIV }\end{array}$ & $216(61.7 \%)$ & $161(61.7 \%)$ & $55(61.8 \%)$ & $\begin{array}{l}0.96 \\
p=0.87\end{array}$ & $168(60.9 \%)$ & $46(63.9 \%)$ & $\begin{array}{l}1.21 \\
p=0.50\end{array}$ \\
\hline $\begin{array}{l}\text { Q6. Syringe } \\
\text { decriminalization } \\
\text { would be good } \\
\text { for the } \\
\text { community }\end{array}$ & $221(63.1 \%)$ & $155(59.4 \%)$ & $66(74.2 \%)$ & $1.83 p=0.035$ & $168(60.9 \%)$ & $51(70.8 \%)$ & $\begin{array}{l}1.42 \\
p=0.24\end{array}$ \\
\hline $\begin{array}{l}\text { Q7. Syringe } \\
\text { decriminalization } \\
\text { would be good } \\
\text { for law } \\
\text { enforcement }\end{array}$ & $209(59.7 \%)$ & $142(54.4 \%)$ & $67(75.3 \%)$ & $\begin{array}{l}2.31 \\
p=0.004\end{array}$ & $153(55.4 \%)$ & $54(75.0 \%)$ & $\begin{array}{l}1.34 \\
p=0.007\end{array}$ \\
\hline
\end{tabular}

${ }^{a}$ Odds ratio for respondents identified as Black, adjusting for gender and age, expressed as a quadratic polynomial.

${ }^{b}$ Odds ratio for respondents identified as female, adjusting for race and age, expressed as a quadratic polynomial. 